Article

\title{
Degradation of Trace Organic Contaminants by a Membrane Distillation-Enzymatic Bioreactor
}

\author{
Muhammad B. Asif ${ }^{1}$ (D), Faisal I. Hai ${ }^{1, *}$, Jinguo Kang ${ }^{1,2}$, Jason P. van de Merwe ${ }^{3}$, \\ Frederic D. L. Leusch ${ }^{3}$, Kazuo Yamamoto ${ }^{4}$, William E. Price ${ }^{2}$ and Long D. Nghiem ${ }^{1}$ \\ 1 Strategic Water Infrastructure Lab, School of Civil, Mining and Environmental Engineering, \\ University of Wollongong, Wollongong NSW 2522, Australia; mba409@uowmail.edu.au (M.B.A.); \\ jkang@uow.edu.au (J.K.); longn@uow.edu.au (L.D.N.) \\ 2 Strategic Water Infrastructure Lab, School of Chemistry, University of Wollongong, Wollongong NSW 2522, \\ Australia; wprice@uow.edu.au \\ 3 Australian Rivers Institute and Griffith School of Environment, Griffith University, Gold Coast QLD 4222, \\ Australia; j.vandemerwe@griffith.edu.au (J.P.v.d.M.); f.leusch@griffith.edu.au (F.D.L.L.) \\ 4 Environmental Science Centre, Department of Urban Engineering, University of Tokyo, Tokyo 113-0033, \\ Japan; yamamoto@esc.u-tokyo.ac.jp \\ * Correspondence: faisal@uow.edu.au; Tel.: +61-2-42213054
}

Received: 31 July 2017; Accepted: 25 August 2017; Published: 28 August 2017

\begin{abstract}
A high retention enzymatic bioreactor was developed by coupling membrane distillation with an enzymatic bioreactor (MD-EMBR) to investigate the degradation of 13 phenolic and 17 non-phenolic trace organic contaminants (TrOCs). TrOCs were effectively retained (90-99\%) by the MD membrane. Furthermore, significant laccase-catalyzed degradation (80-99\%) was achieved for 10 phenolic and 3 non-phenolic TrOCs that contain strong electron donating functional groups. For the remaining TrOCs, enzymatic degradation ranged from 40 to $65 \%$. This is still higher than those reported for enzymatic bioreactors equipped with ultrafiltration membranes, which retained laccase but not the TrOCs. Addition of three redox-mediators, namely syringaldehyde (SA), violuric acid (VA) and 1-hydroxybenzotriazole (HBT), in the MD-EMBR significantly broadened the spectrum of efficiently degraded TrOCs. Among the tested redox-mediators, VA $(0.5 \mathrm{mM})$ was the most efficient and versatile mediator for enhanced TrOC degradation. The final effluent (i.e., membrane permeate) toxicity was below the detection limit, although there was a mediator-specific increase in toxicity of the bioreactor media.
\end{abstract}

Keywords: enzymatic membrane bioreactor (EMBR); laccase; membrane distillation; redox-mediators; trace organic contaminants (TrOCs)

\section{Introduction}

Laccase (EC 1.10.3.2), a copper-containing oxidoreductase enzyme, has been studied extensively for the degradation of recalcitrant compounds such as phenols and aromatic hydrocarbons [1-5]. In recent years, laccase-catalyzed degradation of trace organic contaminants (TrOCs) such as pharmaceuticals, pesticides, personal care products, industrial chemicals and steroid hormones has gained significant attention [6,7]. These TrOCs occur ubiquitously in municipal wastewater and have the potential to adversely affect aquatic ecosystems and human health [8-10].

TrOC degradation by laccase depends on a number of factors including $\mathrm{pH}$, temperature, chemical structure of TrOCs and laccase properties [11-13]. In general, effective laccase-catalyzed degradation of TrOCs containing electron donating functional groups (EDGs) such as amine $\left(-\mathrm{NH}_{2}\right)$, alkoxy (-OR) or hydroxyl $(-\mathrm{OH})$ was observed. On the other hand, degradation of TrOCs containing electron withdrawing functional groups $(E W G s)$ such as halogen $(-X)$, amide $\left(-\mathrm{CONR}_{2}\right)$ or nitro 
$\left(-\mathrm{NO}_{2}\right)$ has been reported to be poor or unstable $[11,14]$. Degradation of TrOCs can be improved by adding different natural and synthetic redox-mediators that are low molecular weight compounds capable of exchanging electrons between laccase and TrOCs [15-17].

Initial studies have assessed the performance of laccase-catalyzed TrOC degradation in batch enzymatic bioreactors due to the concern of enzyme washout in a continuous flow system. In an attempt to prevent enzyme washout, an enzymatic membrane bioreactor (EMBR) was developed by coupling an ultrafiltration (UF) membrane to an enzymatic bioreactor [18,19]. Interestingly, during the operation of the EMBR, adsorption of some hydrophobic TrOCs (e.g., amitriptyline, oxybenzone and octocrylene) onto the enzyme gel layer over the membrane surface resulted in enhanced degradation of the adsorbed compounds [18]. In another study, removal of four non-phenolic TrOCs, namely atrazine, sulfamethoxazole, diclofenac and carbamazepine was improved by $15-25 \%$ following the addition of granular activated carbon (GAC) in EMBR. This was probably because simultaneous adsorption of laccase and TrOCs on GAC promoted the interaction of TrOCs with the active sites of laccase [20]. Results from previous studies indicate the complementarity of simultaneous laccase and TrOC retention within EMBR in contrast to only laccase retention by UF membranes utilized in the previously developed EMBRs. Hence, in this study, it is postulated that the integration of an enzymatic bioreactor with a high retention membrane could facilitate the degradation of resistant TrOCs by retaining both laccase and TrOCs.

Different configurations of conventional activated sludge-based high retention membrane bioreactors (HR-MBR), employing membrane distillation (MD), forward osmosis (FO) or nanofiltration (NF) membranes, have been investigated for advanced wastewater treatment [21-24]. Complete TrOC retention in HR-MBR improved the membrane permeate quality, but the poor removal of certain groups of TrOCs such as those containing EWGs led to their accumulation in the bioreactor. This indicates the necessity of formulating means to enhance biodegradation of TrOCs. In this context, it is noteworthy that recent reports confirm enhanced laccase-catalyzed degradation of selected TrOCs that are not amenable to degradation by conventional activated sludge $[25,26]$. However, the performance of a high retention - enzymatic membrane bioreactor for the removal of a wide range of TrOCs remains to be elucidated.

Among the high retention membrane systems, in MD, a vapor-liquid interface is developed around a hydrophobic micro-porous membrane that allows the water to pass through the membrane via diffusion due to vapor pressure gradient. Compared to conventional distillation processes such as fractional distillation, the MD process requires low temperature and could be operated by using low grade heat or solar energy $[27,28]$. Since the mass transfer in the MD process occurs in gaseous phase, it can theoretically achieve $100 \%$ retention of all non-volatile compounds [29]. The standalone MD process has been investigated for seawater desalination [30], industrial wastewater treatment [31], municipal wastewater treatment [32] and TrOC removal [29,33]. Thus, the MD process was selected for coupling to an enzymatic bioreactor in this study.

The aim of this study was to assess the performance of a laccase based membrane distillationenzymatic membrane bioreactor (MD-EMBR) for the removal of TrOCs having diverse physicochemical properties (e.g., EDGs/EWGs, hydrophobicity and phenolic/non-phenolic moieties). A special focus was given to the improvement in TrOC degradation due to the addition of three redox-mediators, namely syringaldehyde (SA), violuric acid (VA) and 1-hydroxybenzotriazole (HBT) at different concentrations. In addition, performance of laccase-mediator systems was systematically compared based on TrOC degradation, enzyme stability and effluent toxicity.

\section{Materials and Methods}

\subsection{Trace Organic Contaminants (TrOCs), Laccase and Mediators}

A set of 30 TrOCs comprising 10 pharmaceuticals, four personal care products, six pesticides, four industrial chemicals, five steroid hormones and one phytoestrogen was selected based on their widespread occurrence in surface water bodies (see Supplementary Data Table S1). Key physicochemical 
properties of the TrOCs including molecular weight, water solubility, hydrophobicity (log D) and volatility $\left(\mathrm{pK}_{\mathrm{H}}\right)$ are presented in Table 1. All TrOCs were purchased from Sigma Aldrich (Sydney, NSW, Australia), and were of analytical grade. A stock solution $(25 \mathrm{mg} / \mathrm{L})$ containing the mixture of $30 \mathrm{TrOCs}$ was prepared in pure methanol, and kept in dark at $-18^{\circ} \mathrm{C}$.

Laccase from genetically modified Aspergillus oryzae was supplied by Novozymes Australia Pty Ltd (Sydney, NSW, Australia). According to the supplier, the enzyme has a molecular weight, purity, activity and density of $56 \mathrm{KDa}, 10 \%(w / w), 150,000 \mu \mathrm{M}_{(\mathrm{DMP})} / \min$ (measured using 2,6-dimethoxy phenol, DMP, as substrate) and $1.12 \mathrm{~g} / \mathrm{mL}$, respectively.

Two N-OH type redox-mediators, namely 1-hydroxybenzotriazole (HBT) and violuric acid (VA), and one phenolic redox-mediator, namely syringaldehyde (SA), were used in this study (see Supplementary Data Table S2). The selected mediators all follow hydrogen atom transfer (HAT) pathway for TrOC degradation [34], but the oxidation of phenolic and $\mathrm{N}-\mathrm{OH}$ type redox-mediators by laccase produces highly reactive phenoxyl and aminoxyl radicals, respectively. The mediators were also purchased from Sigma Aldrich (Sydney, NSW, Australia). A separate stock solution (50 mM) of each redox-mediator was prepared, and stored at $4{ }^{\circ} \mathrm{C}$ in dark.

Table 1. Physicochemical properties of the selected TrOCs.

\begin{tabular}{|c|c|c|c|c|c|c|}
\hline TrOCs & $\begin{array}{l}\text { Chemical } \\
\text { Formula }\end{array}$ & $\begin{array}{l}\text { Molecular } \\
\text { Weight }\end{array}$ & $\begin{array}{c}\log D \text { at } \\
\mathrm{pH}=7\end{array}$ & $\begin{array}{l}\text { Water Solubility } \\
\text { at } 25^{\circ} \mathrm{C}\end{array}$ & $\begin{array}{l}\text { Vapor } \\
\text { Pressure }\end{array}$ & $\begin{array}{c}\mathrm{pK}_{\mathrm{H}} \text { at } \\
\mathrm{pH} 7\end{array}$ \\
\hline & & g/mole & & $\mathrm{mg} / \mathrm{L}$ & (mmHg) & \\
\hline \multicolumn{7}{|c|}{ Non-Phenolic Compounds } \\
\hline Primidone & $\mathrm{C}_{12} \mathrm{H}_{14} \mathrm{~N}_{2} \mathrm{O}$ & 218.25 & 0.83 & 1500 & $6.08 \times 10^{-11}$ & 13.93 \\
\hline Ketoprofen & $\mathrm{C}_{16} \mathrm{H}_{14} \mathrm{O}_{3}$ & 254.28 & 0.19 & 554,000 & $3.32 \times 10^{-8}$ & 13.70 \\
\hline Naproxen & $\mathrm{C}_{14} \mathrm{H}_{14} \mathrm{O}_{3}$ & 230.26 & 0.73 & 435,000 & $3.01 \times 10^{-7}$ & 12.68 \\
\hline Gemfibrozil & $\mathrm{C}_{15} \mathrm{H}_{22} \mathrm{O}_{3}$ & 250.33 & 2.07 & 263,000 & $6.13 \times 10^{-7}$ & 12.11 \\
\hline Metronidazole & $\mathrm{C}_{6} \mathrm{H}_{9} \mathrm{~N}_{3} \mathrm{O}_{3}$ & 171.15 & -0.14 & 29,000 & $2.67 \times 10^{-7}$ & 11.68 \\
\hline Diclofenac & $\mathrm{C}_{14} \mathrm{H}_{11} \mathrm{Cl}_{2} \mathrm{NO}_{2}$ & 296.15 & 1.77 & 20,000 & $1.59 \times 10^{-7}$ & 11.51 \\
\hline Fenoprop & $\mathrm{C}_{9} \mathrm{H}_{7} \mathrm{Cl}_{3} \mathrm{O}_{3}$ & 269.51 & -0.13 & 230,000 & $2.13 \times 10^{-6}$ & 11.48 \\
\hline Ibuprofen & $\mathrm{C}_{13} \mathrm{H}_{18} \mathrm{O}_{2}$ & 206.28 & 0.94 & 928,000 & $1.39 \times 10^{-4}$ & 10.39 \\
\hline Ametryn & $\mathrm{C}_{9} \mathrm{H}_{17} \mathrm{~N}_{5} \mathrm{~S}$ & 27.33 & 2.97 & 140 & $1.72 \times 10^{-6}$ & 9.35 \\
\hline Clofibric acid & $\mathrm{C}_{10} \mathrm{H}_{11} \mathrm{ClO}_{3}$ & 214.65 & -1.06 & 100,000 & $1.03 \times 10^{-4}$ & 9.54 \\
\hline Carbamazepine & $\mathrm{C}_{15} \mathrm{H}_{12} \mathrm{~N}_{2} \mathrm{O}$ & 236.27 & 1.89 & 220 & $5.78 \times 10^{-7}$ & 9.09 \\
\hline Octocrylene & $\mathrm{C}_{24} \mathrm{H}_{27} \mathrm{~N}$ & 361.48 & 6.89 & 0.36 & $2.56 \times 10^{-9}$ & 8.47 \\
\hline Amitriptyline & $\mathrm{C}_{20} \mathrm{H}_{23} \mathrm{~N}$ & 277.40 & 2.28 & 83 & $1.50 \times 10^{-6}$ & 8.18 \\
\hline Atrazine & $\mathrm{C}_{8} \mathrm{H}_{14} \mathrm{ClN}_{5}$ & 215.68 & 2.64 & 69 & $1.27 \times 10^{-5}$ & 7.28 \\
\hline Propoxur & $\mathrm{C}_{11} \mathrm{H}_{15} \mathrm{NO}_{3}$ & 209.24 & 1.54 & 800 & $1.53 \times 10^{-3}$ & 6.28 \\
\hline Benzophenone & $\mathrm{C}_{13} \mathrm{H}_{10} \mathrm{O}$ & 182.22 & 3.21 & 150 & $8.23 \times 10^{-4}$ & 5.88 \\
\hline DEET & $\mathrm{C}_{12} \mathrm{H}_{17} \mathrm{NO}$ & 191.3 & 2.42 & 1000 & $5.6 \times 10^{-3}$ & 5.85 \\
\hline \multicolumn{7}{|c|}{ Phenolic Compounds } \\
\hline Enterolactone & $\mathrm{C}_{18} \mathrm{H}_{18} \mathrm{O}_{4}$ & 288.38 & 2.53 & 200 & $3.29 \times 10^{-13}$ & 15.20 \\
\hline Estriol & $\mathrm{C}_{18} \mathrm{H}_{24} \mathrm{O}_{3}$ & 298.33 & 1.89 & 32 & $1.34 \times 10^{-9}$ & 10.78 \\
\hline $17 \alpha$-Ethinylestradiol & $\mathrm{C}_{20} \mathrm{H}_{24} \mathrm{O}_{2}$ & 269.40 & 4.11 & 3.9 & $3.74 \times 10^{-9}$ & 9.47 \\
\hline Oxybenzone & $\mathrm{C}_{14} \mathrm{H}_{12} \mathrm{O}_{3}$ & 228.24 & 3.89 & 2700 & $5.26 \times 10^{-6}$ & 9.23 \\
\hline Estrone & $\mathrm{C}_{18} \mathrm{H}_{22} \mathrm{O}_{2}$ & 270.37 & 3.62 & 5.9 & $1.54 \times 10^{-8}$ & 9.03 \\
\hline $17 \beta$-Estradiol & $\mathrm{C}_{18} \mathrm{H}_{24} \mathrm{O}_{2}$ & 272.38 & 4.15 & 3 & $9.82 \times 10^{-9}$ & 8.93 \\
\hline $17 \beta$-Estradiol-17-acetate & $\mathrm{C}_{20} \mathrm{H}_{26} \mathrm{O}_{3}$ & 314.42 & 5.11 & 1.9 & $9.88 \times 10^{-9}$ & 8.67 \\
\hline Bisphenol A & $\mathrm{C}_{15} \mathrm{H}_{16} \mathrm{O}_{2}$ & 228.29 & 3.64 & 73 & $5.34 \times 10^{-7}$ & 8.66 \\
\hline Salicylic acid & $\mathrm{C}_{7} \mathrm{H}_{6} \mathrm{O}_{3}$ & 138.12 & -1.13 & 2240 & $8.2 \times 10^{-5}$ & 8.18 \\
\hline Pentachlorophenol & $\mathrm{C}_{6} \mathrm{HCl}_{5} \mathrm{O}$ & 266.34 & 2.85 & 4800 & $3.49 \times 10^{-4}$ & 7.59 \\
\hline Triclosan & $\mathrm{C}_{12} \mathrm{H}_{7} \mathrm{Cl}_{3} \mathrm{O}_{2}$ & 289.54 & 5.28 & 19 & $3.26 \times 10^{-5}$ & 6.18 \\
\hline 4-tert-Butylphenol & $\mathrm{C}_{10} \mathrm{H}_{14} \mathrm{O}$ & 150.22 & 3.40 & 1000 & 0.0361 & 5.15 \\
\hline 4-tert-Octylphenol & $\mathrm{C}_{14} \mathrm{H}_{22} \mathrm{O}$ & 206.32 & 5.18 & 62 & $1.98 \times 10^{-3}$ & 5.06 \\
\hline
\end{tabular}

\subsection{Experimental Setup}

The laboratory scale MD-EMBR setup comprised a glass enzymatic bioreactor (1.5 L) and an external direct contact membrane distillation system (Figure 1). The glass enzymatic bioreactor 
covered with aluminum foil was placed in a water bath, and the temperature of the water bath was maintained at $30 \pm 0.2{ }^{\circ} \mathrm{C}$ using an immersion heating unit (Julabo, Seelbach, Germany). The enzymatic bioreactor was equipped with an air pump (ACO-002, Zhejiang Sensen Industry Co. Ltd., Zhoushan, China) to maintain a dissolved oxygen concentration of above $3 \mathrm{mg} / \mathrm{L}$.

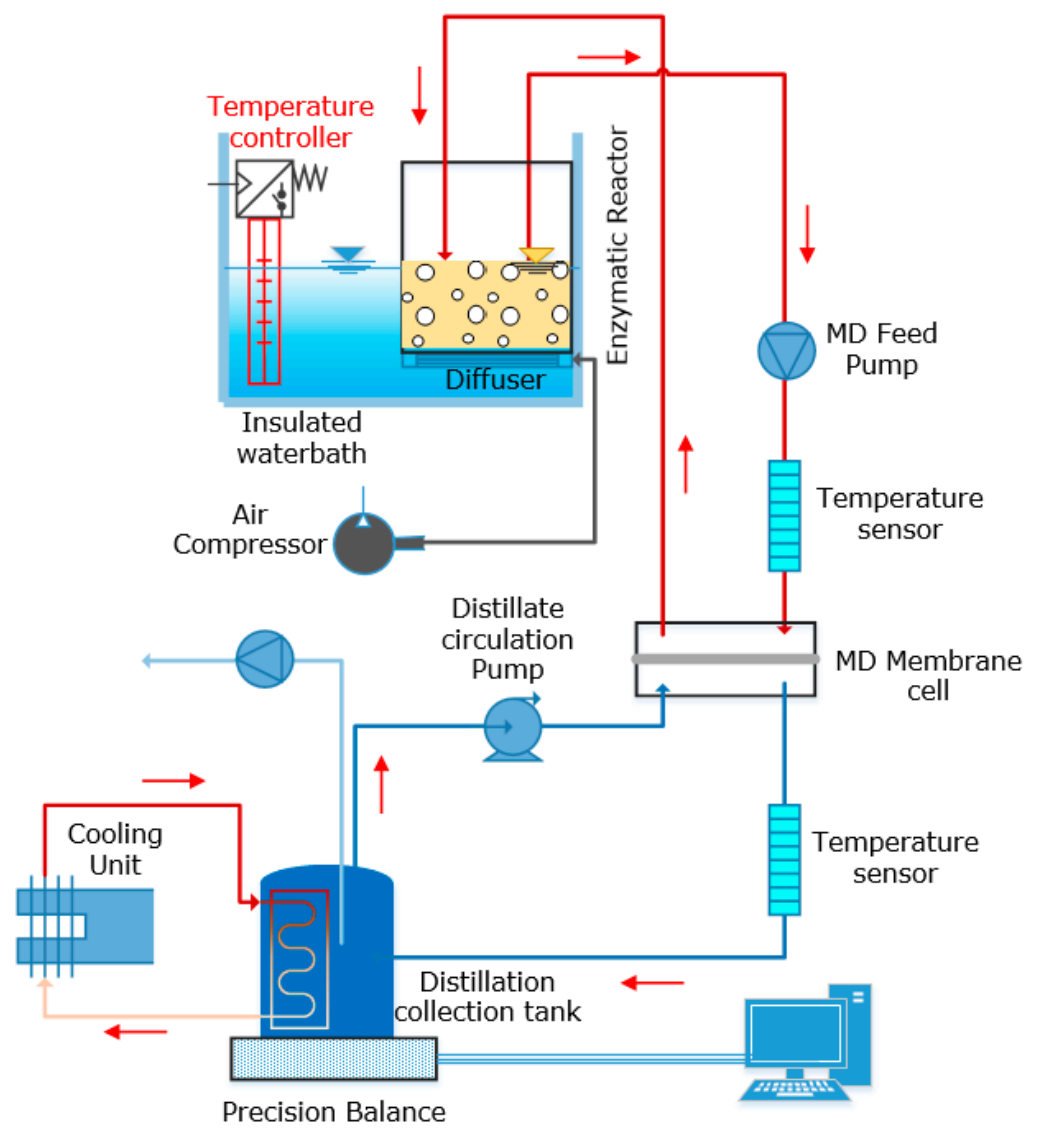

Figure 1. Schematic representation of the membrane distillation-enzymatic membrane bioreactor (MD-EMBR).

The external direct contact membrane distillation system contained an acrylic glass membrane cell, two circulation pumps (Micropump Inc., Vancouver, WA, USA) and a glass permeate tank (Figure 1). Feed and permeate flow channels were engraved on each block of the membrane cell. Length, width and height of each flow channel were 145, 95 and $3 \mathrm{~mm}$, respectively.

A hydrophobic microporous polytetrafloroethylene (PTFE) membrane (GE, Minnetonka, MN, USA) was used during each experiment. The PTFE membrane has a nominal pore size of $0.22 \mu \mathrm{m}$, thickness of $175 \mu \mathrm{m}$, porosity of $70 \%$ and an active layer thickness of $5 \mu \mathrm{m}$ [35].

\subsection{Experimental Protocol}

A series of experiments was carried out to evaluate the performance of MD-EMBR for TrOC degradation. At the start of the experiment, a mixture of the selected TrOCs (each at $20 \mu \mathrm{g} / \mathrm{L}$ ) in Milli-Q water was added to the bioreactor. Laccase was added to the bioreactor for achieving an initial enzymatic activity of $95-100 \mu \mathrm{M}_{(\mathrm{DMP})} / \mathrm{min}$. The media from the glass enzymatic bioreactor and water from the permeate tank were recirculated in their respective flow channels separated by the membrane. A chiller (SC100-A10, Thermo Scientific, Waltham, MA, USA) was used to regulate the temperature of the permeate tank at $10 \pm 0.1^{\circ} \mathrm{C}$. The permeate tank was also placed on a precision balance (Mettler Toledo Inc., Columbus, OH, USA) to monitor permeate flux. The recirculation flow rate of both feed 
and the distillate was controlled at $1 \mathrm{~L} / \mathrm{min}$ (corresponding to the cross flow velocity of $9 \mathrm{~cm} / \mathrm{s}$ ) using two rotameters.

Duplicate samples from the enzymatic bioreactor (100 mL each) and permeate tank (500 mL each) were taken after operating the MD-EMBR for $12 \mathrm{~h}$. After evaluating the laccase-catalyzed degradation of TrOCs in MD-EMBR, the possible improvement in TrOC degradation was assessed with the addition of three redox-mediators (HBT, VA and SA) at two different concentrations ( 0.25 and $0.5 \mathrm{mM})$ via separate runs. Again duplicate samples from the enzymatic bioreactor and permeate tank were collected for the quantification of TrOCs.

Samples collected from the enzymatic bioreactor were diluted to $500 \mathrm{~mL}$ with Milli-Q water and were filtered through $0.45 \mu \mathrm{m}$ glass fiber filter paper (Filtech, Wollongong, NSW, Australia). The $\mathrm{pH}$ of samples was adjusted to 2-2.5 using $4 \mathrm{M} \mathrm{H}_{2} \mathrm{SO}_{4}$ before solid phase extraction (SPE) and GC/MS analysis. For toxicity analysis, undiluted samples from the enzymatic bioreactor and permeate tank were collected in $2 \mathrm{~mL}$ amber vials at the end of each experiment, and stored at $4{ }^{\circ} \mathrm{C}$ until analysis.

\subsection{Analytical Methods}

\subsubsection{TrOC Analysis}

The concentration of TrOCs was measured using an analytical method involving SPE derivatization and quantitative determination by a Shimadzu GC/MS (QP5000) system as described by Hai et al. [36]. Limit of detection (LOD) for this method was compound specific and ranged from 1 to $20 \mathrm{ng} / \mathrm{L}$ (see Supplementary Data Table S1). Removal efficiencies by the enzymatic bioreactor $\left(\mathrm{R}_{1}\right)$ and the MD-EMBR $\left(R_{2}\right)$ were calculated using Equations (1) and (2), respectively:

$$
\begin{aligned}
& \mathrm{R}_{1}=100 \times\left(1-\mathrm{C}_{\mathrm{f}} / \mathrm{C}_{\mathrm{o}}\right) \\
& \mathrm{R}_{2}=100 \times\left(1-\mathrm{C}_{\mathrm{p}} / \mathrm{C}_{\mathrm{o}}\right)
\end{aligned}
$$

where, $\mathrm{C}_{\mathrm{o}}$ and $\mathrm{C}_{\mathrm{f}}$ are the concentration (ng/L) of specific TrOC in the enzymatic bioreactor at the beginning $(t=0 \mathrm{~h})$ and end $(t=12 \mathrm{~h})$ of experiment, respectively, while $\mathrm{C}_{\mathrm{p}}$ is the concentration of specific TrOC in permeate at $t=12 \mathrm{~h}$. The enzymatic transformation/degradation of TrOCs in the MD-EMBR was calculated using Equation (3):

$$
\mathrm{C}_{\mathrm{o}} \times \mathrm{V}_{\mathrm{o}}=\left(\mathrm{C}_{\mathrm{f}} \times \mathrm{V}_{\mathrm{f}}\right)+\left(\mathrm{C}_{\mathrm{p}} \times \mathrm{V}_{\mathrm{p}}\right)+\text { biodegradation }
$$

where, $\mathrm{V}_{\mathrm{o}}, \mathrm{V}_{\mathrm{f}}$ and $\mathrm{V}_{\mathrm{p}}$ represents the volume of feed (at $t=0 \mathrm{~h}$ ), supernatant $(t=12 \mathrm{~h}$ ) and permeate $(t=12 \mathrm{~h})$, respectively.

\subsubsection{Enzymatic Activity, ORP and Toxicity Assay}

Laccase activity and effluent toxicity were examined as described elsewhere [18]. Laccase activity was measured by recording the change in absorbance at $468 \mathrm{~nm}$ due to the oxidation of 2,6-dimethoxyl phenol (DMP) in the presence of $100 \mathrm{mM}$ sodium citrate ( $\mathrm{pH} 4.5)$. Laccase activity expressed as $\mu \mathrm{M}_{(\mathrm{DMP})} / \mathrm{min}$ was then calculated from the molar extinction coefficient of $49.6 / \mathrm{mM} \mathrm{cm}$. Oxidation reduction potential (ORP) was measured at the start and end of each experiment using an ORP meter (WP-80D dual pH-mV meter, Thermo Fisher Scientific, Scoresby, VIC, Australia). Samples for toxicity analysis were collected from the enzymatic bioreactor and permeate tank at end of each experiment. Toxicity, expressed as a relative toxicity unit (rTU), was analyzed by measuring the inhibition of luminescence in the naturally bioluminescent bacteria, Photobacterium leiognathi, as previously described $[37,38]$. 


\section{Results and Discussion}

\subsection{Overall Removal of TrOCs}

In theory, MD membranes can retain all but the volatile organic compounds. In this study, the concentration of non-volatile $\left(\mathrm{pK}_{\mathrm{H}}>9\right)$ TrOCs in the permeate of the MD-EMBR was below the limit of detection of GC/MS. This is consistent with the observation in a previous study, where an MD membrane was coupled with an activated sludge bioreactor [22]. On the other hand, the MD system achieved 90-99\% removal of relatively volatile TrOCs having $\mathrm{pK}_{\mathrm{H}}<9$ (Figure 2). This compares favorably to their previously reported moderate to high removal (54-99\%) by a standalone MD system [29]. In particular, removal of octocrylene $\left(\mathrm{pK}_{\mathrm{H}}=8.47\right)$, benzophenone $\left(\mathrm{pK} \mathrm{K}_{\mathrm{H}}=5.88\right)$, 4-tert-butylphenol $\left(\mathrm{pK}_{\mathrm{H}}=5.15\right)$, 4-tert-octylphenol $\left(\mathrm{pK}_{\mathrm{H}}=5.06\right)$ by the MD-EMBR was above $99 \%$, compared to their 55-70\% removal by the MD only [29]. These results suggest that the coupling of enzymatic degradation process to the MD system was favorable for achieving high TrOC removal.

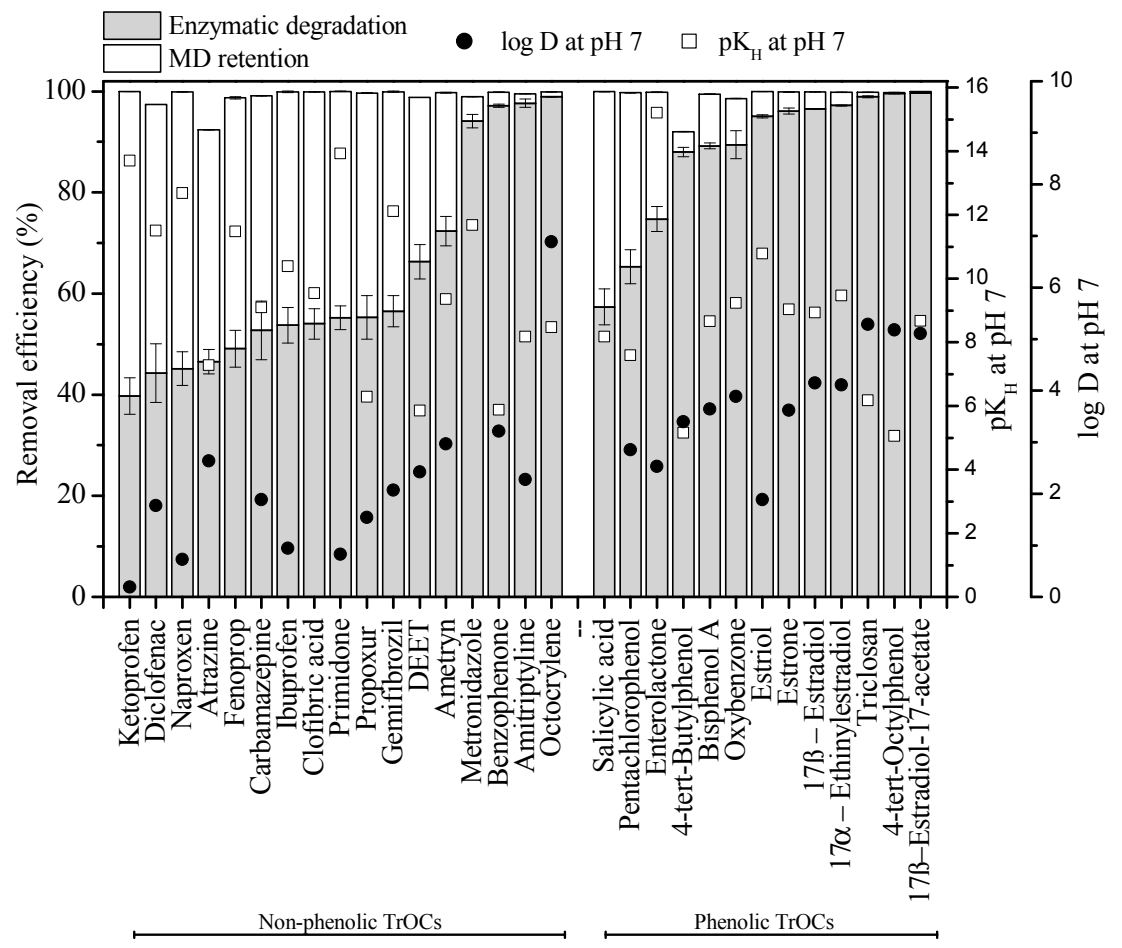

Figure 2. Overall removal and enzymatic degradation of 30 TrOCs in the MD-EMBR. Error bars indicate the standard deviation of duplicate samples. MD-EMBR operating conditions: the initial TrOC concentration and laccase activity was $20 \mu \mathrm{g} / \mathrm{L}$ and $95-100 \mu \mathrm{M}_{(\mathrm{DMP})} / \mathrm{min}$, respectively; temperature of the enzymatic bioreactor and the permeate tank were kept at 30 and $10^{\circ} \mathrm{C}$, respectively; and cross-flow rate of media from the enzymatic bioreactor and distillate was $1 \mathrm{~L} / \mathrm{min}$ (corresponding to a cross-flow velocity of $9 \mathrm{~cm} / \mathrm{s}$ ).

\subsection{TrOC Degradation in Enzymatic Bioreactor}

Degradation of a substrate by laccase involves the transfer of an electron from the substrate to laccase with concomitant reduction of atmospheric oxygen to water. The extent of degradation depends on, among others, the molecular properties (e.g., EWGs, EDGs or phenolic moiety) of the target substrate [11,39]. In this study, high degradation (87-99\%) of 10 out 13 phenolic TrOCs was achieved by the MD-EMBR (Figure 2). These included five steroid hormones (estriol, estrone, $17 \beta$-estradiol, $17 \alpha$-ethinylestradiol and 17 $\beta$-estradiol-17-acetate (95-99\%)), two industrial chemicals (4-tert-butylphenol, and 4-tert-octylphenol (87-99\%)) and two personal care products (oxybenzone 
and triclosan (89-98\%)). On the other hand, enzymatic degradation of some phenolic compounds, namely pentachlorophenol, enterolactone and salicylic acid, ranged from 55 to $75 \%$. Their incomplete degradation, despite the presence of a strong EDG (i.e., hydroxyl group), can be attributed to the concomitant presence of an EWG (e.g., halogen) in their molecular structure (see Supplementary Data Table S1) [39].

Depending on the medium ORP, laccase can also degrade non-phenolic compounds. However, the reaction kinetics can be slow [17,39]. In this study, the enzymatic degradation of 17 non-phenolic TrOCs varied from 40-99\% (Figure 2). Laccase catalyzed degradation of 13 compounds fell in the range of $40-65 \%$, while the degradation of the remaining four TrOCs was in the range of $94-98 \%$. The well degraded non-phenolic TrOCs include metronidazole, benzophenone, amitriptyline and octocrylene. High laccase-catalyzed degradation (80-99\%) in continuous flow UF-EMBR has been previously reported [18,37] for benzophenone, amitriptyline and octocrylene, but not for metronidazole. Metronidazole contains both EWGs (i.e., $-\mathrm{NO}_{2}$ ) and EDGs (i.e., methyl and hydroxyethyl) in its molecule (see Supplementary Data Table S1). High enzymatic degradation of metronidazole following its complete retention by the MD membrane in MD-EMBR can be attributed to the prolonged contact time that may have promoted the interaction of laccase with the EDGs of metronidazole.

An overall degradation of only 40-65\% was achieved by the MD-EMBR for a number of non-phenolic TrOCs (Figure 2), however, these removal efficiencies in fact compare favorably with those reported in the literature $[12,15,37]$. For instance, laccase catalyzed degradation of carbamazepine, clofibric acid, fenoprop and atrazine has been reported to be less than $10 \%$ in both batch and continuous flow ultrafiltration based enzymatic bioreactors $[15,18,40]$. By contrast, $40-45 \%$ degradation of these TrOCs by the MD-EMBR was observed in this study. Since most of the selected non-phenolic TrOCs contain both EWGs and EDGs in their structure (see Supplementary Data Table S1), complete retention of these TrOCs in the enzymatic bioreactor may have facilitated the interaction of EDGs with nearby redox centers, thereby providing higher possibility of electron transfer to enzyme [17]. Previously, Nguyen et al. [20] reported that dosing of GAC into an UF-EMBR led to simultaneous adsorption of laccase and TrOCs on GAC, yielding significant improvement in the degradation of four non-phenolic TrOCs, namely atrazine, sulfamethoxazole, diclofenac and carbamazepine. Although our approach was different, it is conceivable that prolonged retention of TrOCs in the enzymatic bioreactor can improve their degradation.

It is noteworthy that phenolic TrOCs (e.g., triclosan, oxybenzone, bisphenol A and steroid hormones) can act as redox-mediators, and the fragments of phenoxyl radicals formed following their degradation by laccase can oxidize non-phenolic compounds [39]. Indeed Margot et al. [12] observed that degradation of diclofenac by laccase was significantly higher in the mixture of TrOCs containing diclofenac, bisphenol A and mefenamic acid than its degradation as a single compound. It is possible that complete retention of phenoxyl radicals formed due to the degradation of phenolic TrOCs aided better degradation of non-phenolic TrOCs by MD-EMBR as compared to previously developed UF-EMBR [18,37]. Further investigation would be required to substantiate this hypothesis but that is beyond the scope of this study.

This study confirms for the first time the improvement in TrOC degradation in an enzymatic bioreactor by coupling with it a high retention membrane (such as membrane distillation) as compared to a conventional ultrafiltration membrane. We used a direct contact membrane distillation module, but there may be case-specific scope of choice between different formats of membrane distillation. Future studies are recommended to assess the commercial viability of different configurations of MD such as vacuum MD and air gap MD, but that is beyond the scope of this study.

\subsection{Impact of Mediator Addition on TrOC Degradation}

As noted in Section 3.2, of the 30 TrOCs tested, MD-EMBR achieved high degradation (85-99\%) for 14 compounds (10 phenolic and 4 non-phenolic compounds) but the degradation efficiency varied widely $(40-70 \%)$ for the rest of the compounds. To improve the degradation of the latter group, 
three redox-mediators, namely SA, VA and HBT, were added at 0.25 and $0.5 \mathrm{mM}$ concentrations each in separate runs. Depending on the redox-mediator type and concentration, degradation of phenolic compounds and non-phenolic compounds by the MD-EMBR was improved by $20-30 \%$ and $10-50 \%$, respectively (Figure 3) as explained in the following sections.

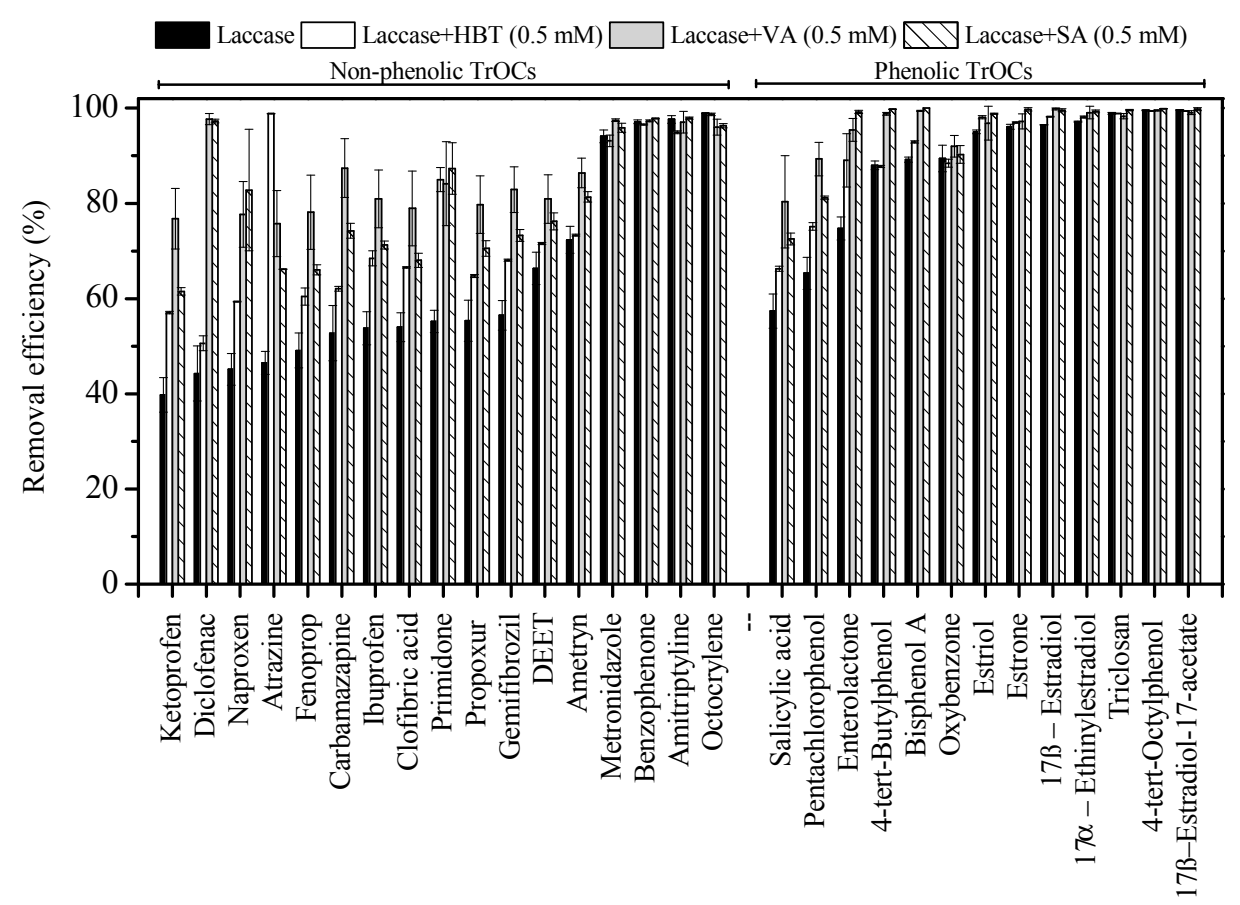

Figure 3. Enzymatic degradation of 30 TrOCs in the presence of three mediators, namely HBT, VA and SA (separately at $0.5 \mathrm{mM}$ ) in the MD-EMBR. Error bars indicate the standard deviation of duplicate samples. Operating conditions of the MD-EMBR are given in the caption of Figure 2.

\subsubsection{Comparison of Redox-Mediators}

To date, the impact of redox-mediator type on the improvement of TrOC degradation has been assessed mainly in small scale and batch tests [34,41,42]. For instance, Ashe et al. [34] investigated the performance of seven different redox-mediators including SA, HBT and VA for the degradation of four resistant TrOCs, namely atrazine, naproxen, oxybenzone and pentachlorophenol in $10 \mathrm{~mL}$ batch reactors. They achieved significant improvement $(40-90 \%)$ at a concentration of $1 \mathrm{mM}$. Nguyen et al. [18] achieved enhanced (10-90\%) removal of TrOCs in UF-EMBR using SA and HBT. However, this is the first study investigating the efficacy of SA, VA and HBT for enhanced degradation of a broad spectrum of TrOCs by an MD-EMBR.

All the tested redox-mediators enhanced the degradation of TrOCs. However, the best overall performance was shown by VA (Figure 3). In line with the findings of Nguyen et al. [37], degradation of the phenolic TrOCs that were already highly degraded by laccase (Figure 2) remained almost the same after the addition of redox-mediators. For the remaining phenolic TrOCs, VA (at $0.5 \mathrm{mM}$ ), compared to HBT and SA achieved better removal for two compounds, namely salicylic acid (80\%) and pentachlorophenol (90\%). Both VA and SA achieved above $95 \%$ degradation of enterolactone, which compares favorably with $45-70 \%$ degradation achieved in absence of mediators (Figure 3).

Of the 17 non-phenolic compounds, degradation of four compounds viz metronidazole, benzophenone, amitriptyline and octocrylene, was at least $90 \%$, regardless of the mediator type (Figure 3). For the remaining compounds, VA (at $0.5 \mathrm{mM}$ ) achieved better degradation for 10 compounds compared to SA and HBT. SA (at $0.5 \mathrm{mM}$ ) performed the best for the degradation of two compounds, namely naproxen and primidone. It is well-known that the herbicide atrazine is resistant 
to laccase catalyzed degradation [18]. Compared to other redox-mediators, HBT was particularly efficient $(>99 \%)$ for the degradation of atrazine. Although a superior ability of VA compared to other mediators for the degradation of non-phenolic TrOCs has been reported previously in a batch enzymatic bioreactor spiked with four TrOCs [34], the effectiveness of VA for the degradation of a broad spectrum of non-phenolic TrOCs is demonstrated for the first time in this study.

\subsubsection{Impact of Mediator Concentration}

Redox-mediator dose can affect TrOC degradation by changing the abundance, stability and reversibility of the generated radicals [43]. Therefore, the impact of two mediator concentrations ( 0.25 and $0.5 \mathrm{mM})$ on ORP, TrOC degradation, and enzyme stability was investigated.

Concentration-dependent improvement in the degradation of 18 TrOCs (5 phenolic and 13 non-phenolic compounds, Figure 4) was observed in MD-EMBR. The highest improvement in the degradation of TrOCs was achieved at $0.5 \mathrm{mM}$. Notably, increasing the concentration of SA, HBT and VA from 0.25 to $0.5 \mathrm{mM}$ improved TOC degradation by up to $7 \%, 15 \%$ and $25 \%$, respectively (Figure 4). This corresponds well with the respective increase of $2 \%, 5 \%$ and $15 \%$ of the reaction media ORP (Figure 5). On the other hand, degradation of 8 phenolic and 4 non-phenolic TrOCs in MD-EMBR was comparable at all the tested mediator concentrations (Supplementary data Figure S3). For instance, HBT achieved over 99\% degradation of atrazine in MD-EMBR irrespective of the mediator concentration. This is consistent with HBT performance reported in case of UF-EMBR [18].

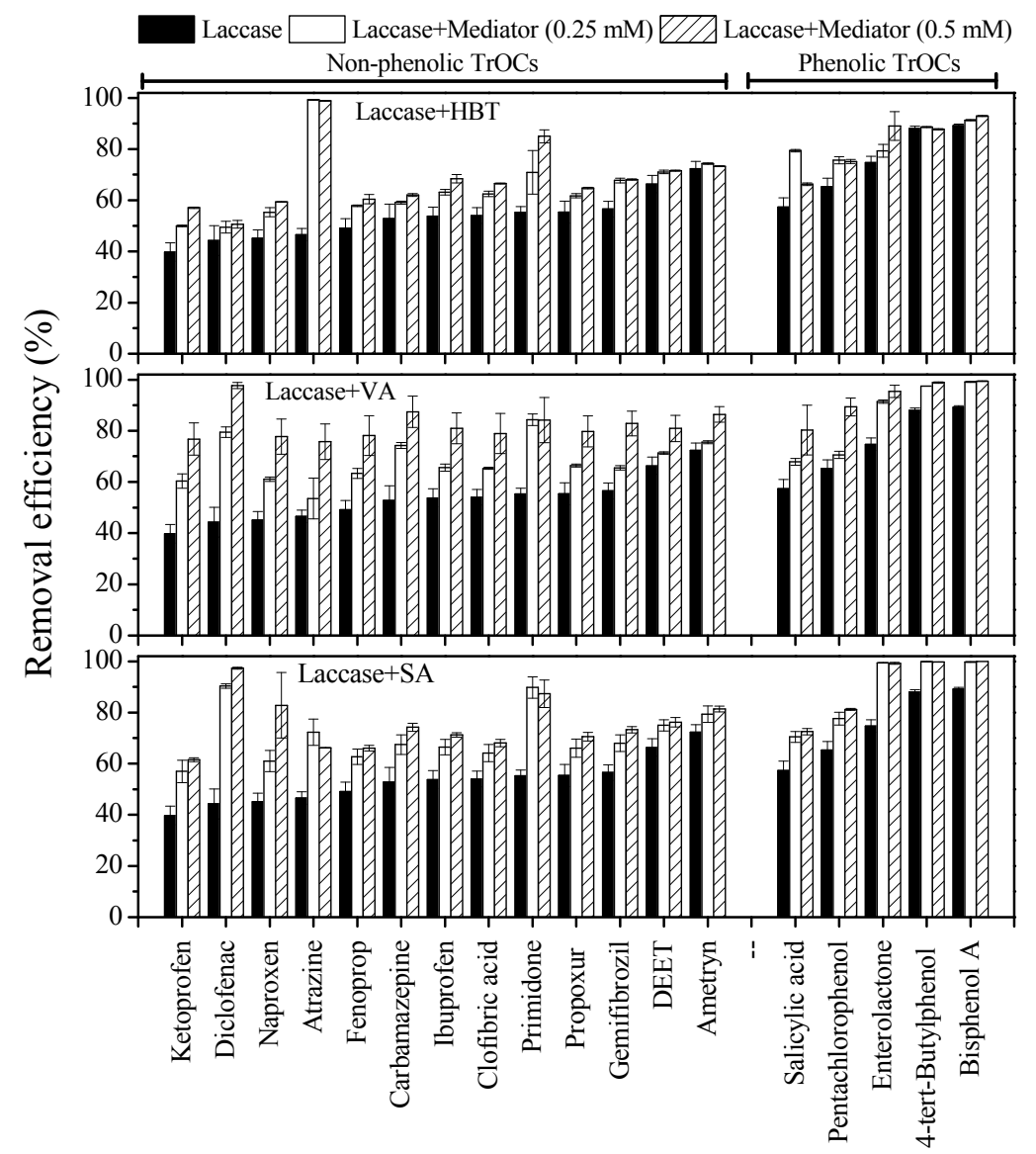

Figure 4. Impact of mediator concentration $(0.25$ and $0.5 \mathrm{mM})$ on the degradation of TrOCs in the MD-EMBR. Error bars indicate the standard deviation of duplicate samples. Operating conditions of the MD-EMBR are given in the caption of Figure 2. Only those TrOCs showing mediator concentration-dependent improvement in their degradation are shown here. For remaining TrOCs, results are given in Supplementary Data Figure S3. 


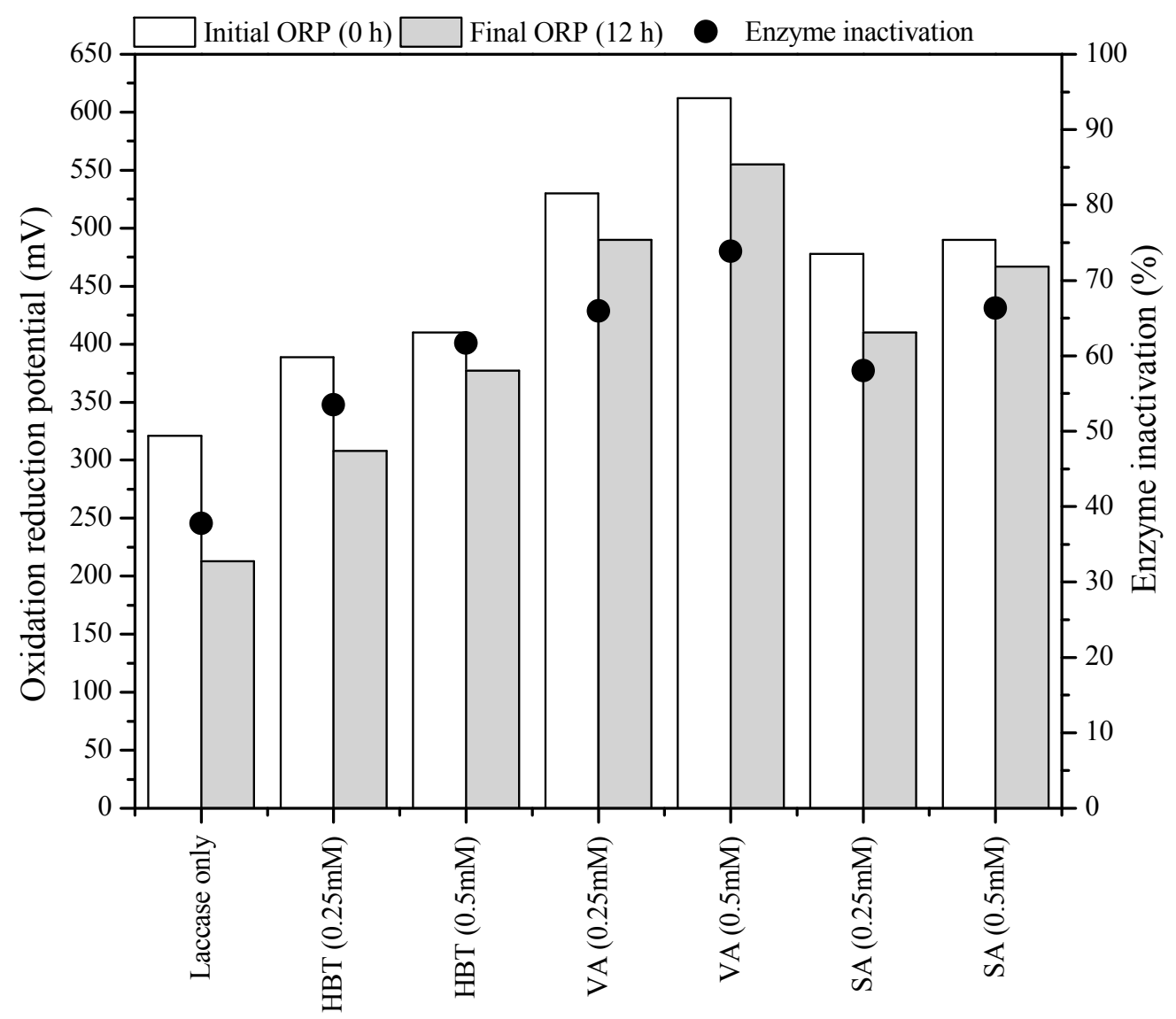

Figure 5. Effect of mediator type and concentration on oxidation reduction potential (ORP) and laccase inactivation in the MD-EMBR. Operating conditions of the MD-EMBR are given in the caption of Figure 2.

In general, the degradation of TrOCs that are easily amenable to laccase (Supplementary data Figure S3) does not improve significantly (less than 5\% in this study), while the degradation of resistant TrOCs (Figure 4) may improve with the increase in mediator concentration, and may reach a plateau beyond a certain mediator concentration. However, the mediator concentration beyond which no improvement occurs may depend on the type of mediators as well as the target TrOCs [41,44].

\subsubsection{Effect of Mediators on Enzyme Stability}

In this study, a gradual inactivation of laccase was observed despite the absence of any known chemical inhibitors in the synthetic wastewater (Figure 5). In the absence of redox-mediators, a $37 \%$ laccase inactivation was observed over a period of $12 \mathrm{~h}$. This was possibly due to the blockage of the active enzyme sites by the charged metabolites and/or hydraulic stress during membrane filtration $[25,41]$. Since the MD membrane can conceptually retain all nonvolatile organics including the transformation products/radicals, laccase inactivation with or without the presence of redox-mediators can be expected. The extent of laccase inactivation increased further when the mediators were added $(61 \%, 66 \%$ and $73 \%$ for HBT, SA and VA, respectively, each at a concentration of $0.5 \mathrm{mM})$. The highly reactive radicals generated from mediators can enhance the degradation of TrOCs but at the same time may inactivate laccase [45]. Purich [17] suggested that the metabolites from the oxidation of substrate and/or mediators could react with enzyme to form non-productive complexes, thereby inactivating the enzyme.

The extent of laccase inactivation also depends on the concentration of redox-mediators. For instance, Khlifi-Slama et al. [45] observed a gradual increase in the inactivation of laccase from Trametes trogii 
following a stepwise increase in the concentration of HBT from 0.1 to $10 \mathrm{mM}$. In another study, increasing SA concentration from 0.1 to $1 \mathrm{mM}$ resulted in aggravated inactivation of laccase from Trametes versicolor [42]. These results suggest that the degree of laccase inactivation is strongly influenced by redox-mediator concentration. Indeed, loss in laccase activity was increased by $7 \%, 9 \%$ and $11 \%$ in MD-EMBR due to the increase in the concentration of HBT, SA and VA, respectively, from 0.25 to $0.5 \mathrm{mM}$ (Figure 5). Although laccase activity was greatly affected in the presence of redox-mediators, it was compensated by the improvement in TrOC degradation (Figure 3). For example, the highest drop in laccase activity was observed in the presence of VA (Figure 5), but it outperformed SA and HBT in terms of enhanced TrOC degradation (Figure 3).

\subsection{Effluent Toxicity}

The charged metabolites and highly reactive radicals produced following the oxidation of redox-mediators may improve TrOC degradation $[18,46]$, but these can also cause an increase in effluent toxicity $[18,47]$. In this study, it was not possible to relate individual metabolites to specific parent compounds because we investigated a mixture of 30 TrOCs. Hence, the overall bacterial toxicity of the reaction mixture and permeate was evaluated at the end of each run. Of the three mediators tested, SA significantly increased the toxicity of the solution in the enzymatic bioreactor, whereas HBT and VA showed no effect on toxicity levels (Table 2). Compared to the background toxicity of the mixture of laccase and TrOCs in the enzymatic bioreactor of MD-EMBR $(<1$ to $1.8 \mathrm{rTU} ; n=2)$, toxicity in the enzymatic bioreactor due to addition of HBT, VA and SA ranged from $<1$ to $1.7 \mathrm{rTU}(n=2), 3.3$ to $3.9 \mathrm{rTU}(n=2)$ and 109 to $116 \mathrm{rTU}(n=2)$, respectively. Notably, the final effluent (i.e., membrane permeate) was not toxic to bacteria $(<1 \mathrm{rTU})$ for any of the enzyme/mediator combinations, indicating that MD not only retained TrOCs and laccase but also the transformation byproducts and radicals responsible for inducing bacterial toxicity. This is an added advantage of coupling a high retention membrane to the enzymatic bioreactor.

Table 2. Toxicity of the reactor mixture and permeate following treatment of TrOCs with different mediators in MD-EMBR, expressed as relative toxic unit (rTU). Mediators were added separately at a concentration of $0.5 \mathrm{mM}$. The limit of detection of the toxicity assay was $10 \%$ inhibition of luminescence (i.e., 1 rTU). Toxicity in all permeate samples was below the limit of detection $(n=2)$.

\begin{tabular}{ccc}
\hline Reaction Mixture & Toxicity of the Reactor Mixture (rTU) & Toxicity of the Permeate (rTU) \\
\hline TrOCs + Laccase & $<1-1.8$ & $<1$ \\
TrOCs + Laccase + HBT $(0.5 \mathrm{mM})$ & $<1-1.7$ & $<1$ \\
TrOCs + Laccase + VA $(0.5 \mathrm{mM})$ & $3.3-3.9$ & $<1$ \\
TrOCs + Laccase + SA $(0.5 \mathrm{mM})$ & $109-116$ & $<1$ \\
\hline
\end{tabular}

\subsection{Permeate Flux}

The driving force of permeate flux in MD is the difference between feed and distillate temperature. Ideally, feed and distillate temperature is maintained at over 50 and $20-25^{\circ} \mathrm{C}$, respectively to obtain a permeate flux of approximately $10 \mathrm{~L} / \mathrm{m}^{2} \mathrm{~h}[27,48]$. In this study, however, to avoid thermal inhibition of laccase [46], temperature of the enzymatic reactor and permeate tank was kept at 30 and $10{ }^{\circ} \mathrm{C}$, respectively. A stable permeate flux of around $4 \mathrm{~L} / \mathrm{m}^{2} \mathrm{~h}$ was observed during all experiments (Supplementary Data Figure S4), suggesting that membrane fouling did not occur during the operation period. This level of flux is consistent with the feed temperature employed. Notably, the average permeate flux (Figure 6) for laccase only, laccase-HBT, laccase-VA and laccase-SA variations was $3.69 \pm 0.44 \mathrm{~L} / \mathrm{m}^{2} \mathrm{~h}(n=150), 3.89 \pm 0.63 \mathrm{~L} / \mathrm{m}^{2} \mathrm{~h}(n=283), 3.92 \pm 0.62 \mathrm{~L} / \mathrm{m}^{2} \mathrm{~h}(n=291)$ and $3.86 \pm 0.66 \mathrm{~L} / \mathrm{m}^{2} \mathrm{~h}(n=288) \mathrm{LMH}$, respectively, confirming negligible impact of different type of mediator addition on membrane flux. In this study, the mass transfer coefficient $\left(\mathrm{K}_{\mathrm{m}}\right)$ of the DCMD, which was calculated based on the method described by Nghiem et al. [49], ranged from 1.22 to $1.28\left(\times 10^{-3}\right) \mathrm{L} / \mathrm{m}^{2} \mathrm{~h} \mathrm{~Pa}$. This value is in good agreement with that in previous studies $[48,50]$. 
Thus, this study shows both stable membrane hydraulic performance and improved enzymatic degradation of TrOCs following their complete retention by the MD membrane.

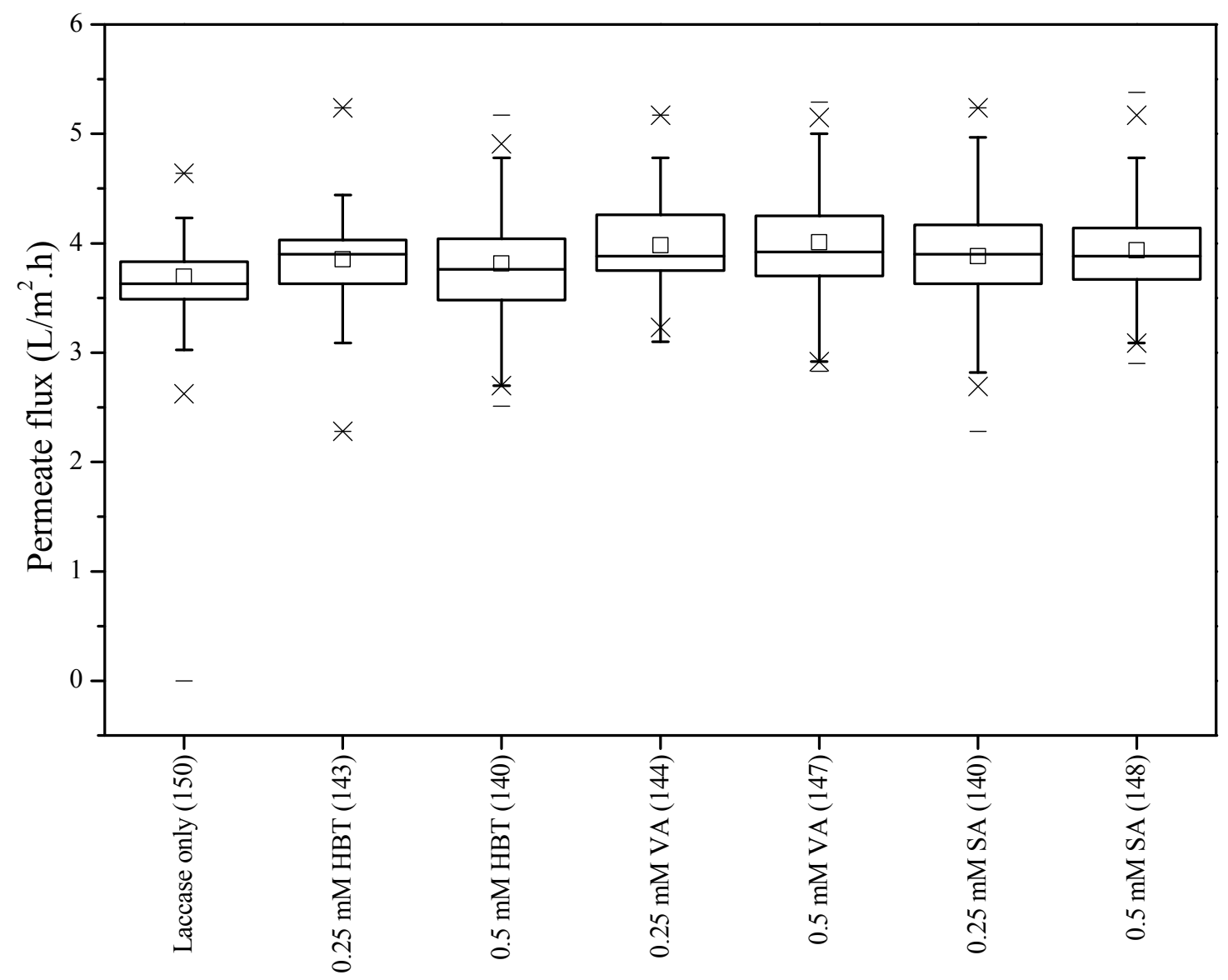

Figure 6. Permeate flux during the operation of MD-EMBR with and without the presence of redox-mediators. Box-and-whisker plot shows the interquartile range; median (horizontal line in the box); min and max (whiskers); average (small square in the box); and 1 and 99\% percentiles (cross above and below the whiskers). Operating conditions for MD-EMBR: Temperature of the enzymatic bioreactor and the permeate tank were kept at 30 and $10{ }^{\circ} \mathrm{C}$, respectively; cross-flow rate of water from enzymatic bioreactor and distillate was $1 \mathrm{~L} / \mathrm{min}$ (corresponding to cross-flow velocity of $9 \mathrm{~cm} / \mathrm{s}$ ); the initial TrOC concentration and laccase activity was $20 \mu \mathrm{g} / \mathrm{L}$ and $95-100 \mu \mathrm{M}_{(\mathrm{DMP})} / \mathrm{min}$, respectively; and each mediator was added at 0.25 or $0.5 \mathrm{mM}$ concentration in separate runs.

\section{Conclusions}

Performance of an enzymatic bioreactor integrated with the MD system (MD-EMBR) was examined for the removal of 13 phenolic and 17 non-phenolic compounds. Based on permeate quality, MD-EMBR achieved 90-99\% TrOC retention. Degradation of TrOCs varied (40-99\%) depending on their molecular properties (electron withdrawing functional groups electron donating functional groups and phenolic moiety). High degradation (above 90\%) of TrOCs containing EDGs in their chemical structure was observed in the MD-EMBR, while those containing EWGs in their molecular structure were moderately degraded (40-75\%). Degradation of TrOCs was further improved by adding three redox-mediators, namely syringaldehyde (SA), violuric acid (VA) and 1-hydroxybenzotriazole (HBT). VA at $0.5 \mathrm{mM}$ concentration was found to be the most effective mediator for improving the degradation of phenolic and non-phenolic TrOCs. Moreover, it was observed that the degradation of non-phenolic compounds in laccase-mediator system was strongly influenced by the tested 
concentration of the redox-mediators. Despite an increase in the toxicity of the reaction mixture caused by SA, the final effluent of the MD-EMBR was nontoxic.

Supplementary Materials: The following are available online at http:/ /www.mdpi.com/2076-3417/7/9/879/s1, Table S1: Physicochemical properties of the selected trace organic contaminants (TrOCs), Table S2: Physicochemical properties of the selected redox-mediators, Figure S3: Impact of mediator concentration $(0.25$ and $0.5 \mathrm{mM})$ on the degradation of after an incubation time of $12 \mathrm{~h}$ in the MD-EMBR. Error bars indicate the standard deviation of duplicate samples. Degradation of these TrOCs did not improve by increasing mediator concentration, Figure S4: Permeate flux obtained during the operation of enzymatic membrane distillation (MD-EMBR) with and without the addition of redox mediators.

Acknowledgments: This research has been conducted with the support of the Australian Government Research Training Program Scholarship. Novozymes Pty. Ltd., Australia is thanked for the provision of enzyme solution. This study was partially funded by the GeoQuEST Research Centre, University of Wollongong, Australia.

Author Contributions: F.I.H. conceived and led the project. F.I.H. and M.B.A. planned the experiments in consultation with the coauthors. M.B.A. conducted the experiments. J.K., F.D.D.L. and J.P.M. analyzed TrOC and toxicity samples. F.I.H. and M.B.A. analyzed the data and prepared the manuscript with the contribution of K.Y., W.E.P., L.D.N., F.D.D.L. and J.P.M. to specific sections.

Conflicts of Interest: The authors declare no conflict of interest.

\section{References}

1. Hai, F.I.; Yamamoto, K.; Nakajima, F.; Fukushi, K. Application of a gac-coated hollow fiber module to couple enzymatic degradation of dye on membrane to whole cell biodegradation within a membrane bioreactor. J. Membr. Sci. 2012, 389, 67-75. [CrossRef]

2. Hai, F.I.; Yamamoto, K.; Fukushi, K. Hybrid treatment systems for dye wastewater. Crit. Rev. Environ. Sci. Technol. 2007, 37, 315-377. [CrossRef]

3. Liu, Y.; Yan, M.; Geng, Y.; Huang, J. Laccase immobilization on poly(p-phenylenediamine) $/ \mathrm{Fe}_{3} \mathrm{O}_{4}$ nanocomposite for reactive blue 19 dye removal. Appl. Sci. 2016, 6, 232. [CrossRef]

4. Hai, F.I.; Yamamoto, K.; Fukushi, K. Development of a submerged membrane fungi reactor for textile wastewater treatment. Desalination 2006, 192, 315-322. [CrossRef]

5. Hai, F.I.; Yamamoto, K.; Nakajima, F.; Fukushi, K.; Nghiem, L.D.; Price, W.E.; Jin, B. Degradation of azo dye acid orange 7 in a membrane bioreactor by pellets and attached growth of Coriolus versicolour. Bioresour. Technol. 2013, 141, 29-34. [CrossRef] [PubMed]

6. Asif, M.B.; Hai, F.I.; Singh, L.; Price, W.E.; Nghiem, L.D. Degradation of pharmaceuticals and personal care products by white-rot fungi-A critical review. Curr. Pollut. Rep. 2017, 3, 88-103. [CrossRef]

7. Asif, M.B.; Hai, F.I.; Hou, J.; Price, W.E.; Nghiem, L.D. Impact of wastewater derived dissolved interfering compounds on growth, enzymatic activity and trace organic contaminant removal of white rot fungi-A critical review. J. Environ. Manag. 2017, 201, 89-109. [CrossRef] [PubMed]

8. Luo, Y.; Guo, W.; Ngo, H.H.; Nghiem, L.D.; Hai, F.I.; Zhang, J.; Liang, S.; Wang, X.C. A review on the occurrence of micropollutants in the aquatic environment and their fate and removal during wastewater treatment. Sci. Total Environ. 2014, 473, 619-641. [CrossRef] [PubMed]

9. Alexander, J.T.; Hai, F.I.; Al-aboud, T.M. Chemical coagulation-based processes for trace organic contaminant removal: Current state and future potential. J. Environ. Manag. 2012, 111, 195-207. [CrossRef] [PubMed]

10. Pal, A.; Gin, K.Y.-H.; Lin, A.Y.-C.; Reinhard, M. Impacts of emerging organic contaminants on freshwater resources: Review of recent occurrences, sources, fate and effects. Sci. Total Environ. 2010, 408, 6062-6069. [CrossRef] [PubMed]

11. Yang, S.; Hai, F.I.; Nghiem, L.D.; Price, W.E.; Roddick, F.; Moreira, M.T.; Magram, S.F. Understanding the factors controlling the removal of trace organic contaminants by white-rot fungi and their lignin modifying enzymes: A critical review. Bioresour. Technol. 2013, 141, 97-108. [CrossRef] [PubMed]

12. Margot, J.; Maillard, J.; Rossi, L.; Barry, D.A.; Holliger, C. Influence of treatment conditions on the oxidation of micropollutants by trametes versicolor laccase. New Biotechnol. 2013, 30, 803-813. [CrossRef] [PubMed]

13. Hai, F.I.; Nghiem, L.D.; Khan, S.J.; Price, W.E.; Yamamoto, K. Wastewater reuse: Removal of emerging trace organic contaminants. In Membrane Biological Reactors: Theory, Modeling, Design, Management and Applications to Wastewater Reuse; Hai, F.I., Yamamoto, K., Lee, C., Eds.; IWA Publishing: London, UK, 2014; pp. 165-205, ISBN 9781780400655. 
14. Hai, F.I.; Tadkaew, N.; McDonald, J.A.; Khan, S.J.; Nghiem, L.D. Is halogen content the most important factor in the removal of halogenated trace organics by mbr treatment? Bioresour. Technol. 2011, 102, 6299-6303. [CrossRef] [PubMed]

15. Tran, N.H.; Urase, T.; Kusakabe, O. Biodegradation characteristics of pharmaceutical substances by whole fungal culture trametes versicolor and its laccase. J. Water Environ. Technol. 2010, 8, 125-140. [CrossRef]

16. Cañas, A.I.; Camarero, S. Laccases and their natural mediators: Biotechnological tools for sustainable eco-friendly processes. Biotechnol. Adv. 2010, 28, 694-705. [CrossRef] [PubMed]

17. Purich, D.L. Enzyme Kinetics: Catalysis \& Control: A Reference of Theory and Best-Practice Methods; Elsevier: Amsterdam, The Netherlands, 2010; p. 759, ISBN 9780123809247.

18. Nguyen, L.N.; Hai, F.I.; Price, W.E.; Kang, J.; Leusch, F.D.; Roddick, F.; van de Merwe, J.P.; Magram, S.F.; Nghiem, L.D. Degradation of a broad spectrum of trace organic contaminants by an enzymatic membrane reactor: Complementary role of membrane retention and enzymatic degradation. Int. Biodeterior. Biodegrad. 2015, 99, 115-122. [CrossRef]

19. Lloret, L.; Eibes, G.; Feijoo, G.; Moreira, M.T.; Lema, J.M. Degradation of estrogens by laccase from myceliophthora thermophila in fed-batch and enzymatic membrane reactors. J. Hazard. Mater. 2012, 213-214, 175-183. [CrossRef] [PubMed]

20. Nguyen, L.N.; Hai, F.I.; Price, W.E.; Leusch, F.D.; Roddick, F.; Ngo, H.H.; Guo, W.; Magram, S.F.; Nghiem, L.D. The effects of mediator and granular activated carbon addition on degradation of trace organic contaminants by an enzymatic membrane reactor. Bioresour. Technol. 2014, 167, 169-177. [CrossRef] [PubMed]

21. Luo, W.; Hai, F.I.; Price, W.E.; Guo, W.; Ngo, H.H.; Yamamoto, K.; Nghiem, L.D. High retention membrane bioreactors: Challenges and opportunities. Bioresour. Technol. 2014, 167, 539-546. [CrossRef] [PubMed]

22. Wijekoon, K.C.; Hai, F.I.; Kang, J.; Price, W.E.; Guo, W.; Ngo, H.H.; Cath, T.Y.; Nghiem, L.D. A novel membrane distillation-thermophilic bioreactor system: Biological stability and trace organic compound removal. Bioresour. Technol. 2014, 159, 334-341. [CrossRef] [PubMed]

23. Luo, W.; Hai, F.I.; Kang, J.; Price, W.E.; Nghiem, L.D.; Elimelech, M. The role of forward osmosis and microfiltration in an integrated osmotic-microfiltration membrane bioreactor system. Chemosphere 2015, 136, 125-132. [CrossRef]

24. Choi, J.-H.; Dockko, S.; Fukushi, K.; Yamamoto, K. A novel application of a submerged nanofiltration membrane bioreactor (NF MBR) for wastewater treatment. Desalination 2002, 146, 413-420. [CrossRef]

25. Hai, F.I.; Nghiem, L.D.; Modin, O. Biocatalytic membrane reactors for the removal of recalcitrant and emerging pollutants from wastewater. In Handbook of Membrane Reactors: Reactor Types and Industrial Applications; Basile, A., Ed.; Woodhead Publishing: Cambridge, UK, 2013; Volume 2, pp. 763-807, ISBN 9780857094155.

26. Modin, O.; Hai, F.I.; Nghiem, L.D.; Basile, A.; Fukushi, K. Gas-diffusion, extractive, biocatalytic and electrochemical membrane biological reactors. In Membrane Biological Reactors: Theory, Modeling, Design, Management and Applications to Wastewater Reuse; Hai, F.I., Yamamoto, K., Lee, C., Eds.; IWA Publishing: London, UK, 2014; pp. 299-334, ISBN 9781780400655.

27. Alkhudhiri, A.; Darwish, N.; Hilal, N. Membrane distillation: A comprehensive review. Desalination 2012, 287, 2-18. [CrossRef]

28. Qtaishat, M.R.; Banat, F. Desalination by solar powered membrane distillation systems. Desalination 2013, 308, 186-197. [CrossRef]

29. Wijekoon, K.C.; Hai, F.I.; Kang, J.; Price, W.E.; Cath, T.Y.; Nghiem, L.D. Rejection and fate of trace organic compounds (TrOCs) during membrane distillation. J. Membr. Sci. 2014, 453, 636-642. [CrossRef]

30. Duong, H.C.; Duke, M.; Gray, S.; Cooper, P.; Nghiem, L.D. Membrane scaling and prevention techniques during seawater desalination by air gap membrane distillation. Desalination 2016, 397, 92-100. [CrossRef]

31. Li, J.; Wu, J.; Sun, H.; Cheng, F.; Liu, Y. Advanced treatment of biologically treated coking wastewater by membrane distillation coupled with pre-coagulation. Desalination 2016, 380, 43-51. [CrossRef]

32. Phattaranawik, J.; Fane, A.G.; Pasquier, A.C.; Bing, W. A novel membrane bioreactor based on membrane distillation. Desalination 2008, 223, 386-395. [CrossRef]

33. Asif, M.B.; Nguyen, L.N.; Hai, F.I.; Price, W.E.; Nghiem, L.D. Integration of an enzymatic bioreactor with membrane distillation for enhanced biodegradation of trace organic contaminants. Int. Biodeterior. Biodegrad. $\mathbf{2 0 1 7}$, in press. [CrossRef] 
34. Ashe, B.; Nguyen, L.N.; Hai, F.I.; Lee, D.-J.; van de Merwe, J.P.; Leusch, F.D.; Price, W.E.; Nghiem, L.D. Impacts of redox-mediator type on trace organic contaminants degradation by laccase: Degradation efficiency, laccase stability and effluent toxicity. Int. Biodeterior. Biodegrad. 2016, 113, 169-176. [CrossRef]

35. Nghiem, L.D.; Cath, T. A scaling mitigation approach during direct contact membrane distillation. Sep. Purif. Technol. 2011, 80, 315-322. [CrossRef]

36. Hai, F.I.; Tessmer, K.; Nguyen, L.N.; Kang, J.; Price, W.E.; Nghiem, L.D. Removal of micropollutants by membrane bioreactor under temperature variation. J. Membr. Sci. 2011, 383, 144-151. [CrossRef]

37. Nguyen, L.N.; van de Merwe, J.P.; Hai, F.I.; Leusch, F.D.; Kang, J.; Price, W.E.; Roddick, F.; Magram, S.F.; Nghiem, L.D. Laccase-syringaldehyde-mediated degradation of trace organic contaminants in an enzymatic membrane reactor: Removal efficiency and effluent toxicity. Bioresour. Technol. 2016, 200, 477-484. [CrossRef] [PubMed]

38. Van de Merwe, J.P.; Leusch, F.D. A sensitive and high throughput bacterial luminescence assay for assessing aquatic toxicity-The blt-screen. Environ. Sci. Process. Impacts 2015, 17, 947-955. [CrossRef] [PubMed]

39. D'Acunzo, F.; Galli, C.; Gentili, P.; Sergi, F. Mechanistic and steric issues in the oxidation of phenolic and non-phenolic compounds by laccase or laccase-mediator systems. The case of bifunctional substrates. New J. Chem. 2006, 30, 583-591. [CrossRef]

40. Hata, T.; Shintate, H.; Kawai, S.; Okamura, H.; Nishida, T. Elimination of carbamazepine by repeated treatment with laccase in the presence of 1-hydroxybenzotriazole. J. Hazard. Mater. 2010, 181, 1175-1178. [CrossRef] [PubMed]

41. Lloret, L.; Eibes, G.; Moreira, M.; Feijoo, G.; Lema, J. On the use of a high-redox potential laccase as an alternative for the transformation of non-steroidal anti-inflammatory drugs (NSAIDs). J. Mol. Catal. B Enzym. 2013, 97, 233-242. [CrossRef]

42. Nguyen, L.N.; Hai, F.I.; Kang, J.; Leusch, F.D.; Roddick, F.; Magram, S.F.; Price, W.E.; Nghiem, L.D. Enhancement of trace organic contaminant degradation by crude enzyme extract from trametes versicolor culture: Effect of mediator type and concentration. J. Taiwan Inst. Chem. Eng. 2014, 45, 1855-1862. [CrossRef]

43. D'Acunzo, F.; Baiocco, P.; Galli, C. A study of the oxidation of ethers with the enzyme laccase under mediation by two N-OH-type compounds. New J. Chem. 2003, 27, 329-332. [CrossRef]

44. Mizuno, H.; Hirai, H.; Kawai, S.; Nishida, T. Removal of estrogenic activity of iso-butylparaben and n-butylparaben by laccase in the presence of ${ }_{1}$-hydroxybenzotriazole. Biodegradation 2009, 20, 533-539. [CrossRef] [PubMed]

45. Khlifi-Slama, R.; Mechichi, T.; Sayadi, S.; Dhouib, A. Effect of natural mediators on the stability of trametes trogii laccase during the decolourization of textile wastewaters. J. Microbiol. 2012, 50, 226-234. [CrossRef] [PubMed]

46. Kim, Y.-J.; Nicell, J.A. Impact of reaction conditions on the laccase-catalyzed conversion of bisphenol A. Bioresour. Technol. 2006, 97, 1431-1442. [CrossRef] [PubMed]

47. Marco-Urrea, E.; Pérez-Trujillo, M.; Vicent, T.; Caminal, G. Ability of white-rot fungi to remove selected pharmaceuticals and identification of degradation products of ibuprofen by trametes versicolor. Chemosphere 2009, 74, 765-772. [CrossRef]

48. Duong, H.C.; Hai, F.I.; Al-Jubainawi, A.; Ma, Z.; He, T.; Nghiem, L.D. Liquid desiccant lithium chloride regeneration by membrane distillation for air conditioning. Sep. Purif. Technol. 2017, 177, 121-128. [CrossRef]

49. Nghiem, L.D.; Hildinger, F.; Hai, F.I.; Cath, T. Treatment of saline aqueous solutions using direct contact membrane distillation. Desalination Water Treat. 2011, 32, 234-241. [CrossRef]

50. Duong, H.C.; Cooper, P.; Nelemans, B.; Cath, T.Y.; Nghiem, L.D. Optimising thermal efficiency of direct contact membrane distillation by brine recycling for small-scale seawater desalination. Desalination 2015, 374, 1-9. [CrossRef]

(C) 2017 by the authors. Licensee MDPI, Basel, Switzerland. This article is an open access article distributed under the terms and conditions of the Creative Commons Attribution (CC BY) license (http:/ / creativecommons.org/licenses/by/4.0/). 